\title{
The paradigm of the migration crisis and its influence on national legislation on irregular migration
}

\author{
Paradygmat kryzysu migracyjnego i jego wpływ na legislację w obszarze \\ migracji nieregularnej
}

Парадигма миграционного кризиса и ее влияние на законодательство в области нерегулярной миграции

JOANNA MARKIEWICZ-STANNY

Dr., University of Zielona Góra

e-mail: j.markiewicz-stanny@wpa.uz.zgora.pl, https://orcid.org/0000-0002-1842-7243

\begin{abstract}
Summary: The aim of this article is to provide a detailed study of the ways in which the paradigm of crisis has influenced the law and practice of European countries in the field of irregular migration. Bearing in mind that the perception of "crisis" is ambiguous and does not have legal definition, the first part of this paper will provide a clarification of its scope and some contexts in which it is used. Secondly, labelling some situations as "crises" requires some urgent and unusual actions. Hence, it is important to indicate what types of legal measures and normative solutions, therefore, prevail nowadays in the practice of states. The countries that are particularly interesting in this context include Germany, Sweden, and Denmark, whose migration policies have, over the course of the past few years, decisively shifted from a relatively open approach towards more restrictive solutions. Although the crisis in the migration context is defined bipolarly, a characteristic feature of the paradigm shift is focusing on the elimination or at least limitation of the presence of foreigners on the territory of the state through border controls, obstruction of access to international protection and family reunification, as well as increasing the effectiveness of forced returns. The result of these consideration has led to the conclusion that on the one hand the authorities' rhetoric of crisis not automatically mean the use of special and emergency measures foreseen by law. On the other hand, the narrative referring to defeat and catastrophe justified the introduction of controversial solutions in a hurry, often with disregard for the detailed analyses and regulatory impact assessment, which are common in such cases. At the same time, the determinant of the shape of the migration law is the "temporariness" inherent in the crisis paradigm. One of its most important elements is the departure from long-term residence permits, guaranteeing a certain stability in connection with international protection, in favour of short-term permits.
\end{abstract}

Key words: irregular migration, migration crisis, legislation

Streszczenie: Celem artykułu jest szczegółowe zbadanie, w jaki sposób paradygmat kryzysu wpływa na prawo i praktykę krajów europejskich w zakresie nieregularnej migracji. Mając na uwadze, że pojęcie kryzysu jest niejednoznaczne i nie ma definicji prawnej, w pierwszej części artykułu wyjaśniono jego zakres i kontekst, w jakim się go stosuje. Po drugie, oznaczanie niektórych sytuacji jako kryzysów wymaga pilnych i nietypowych działań. Stąd ważne jest wskazanie, jakie rodzaje środków prawnych i rozwiązań normatywnych przeważają współcześnie w praktyce państw. Szczególnie interesujące w tym kontekście pozostają takie państwa, jak Niemcy, Szwecja czy Dania, które w perspektywie ostatnich kilku lat w swojej polityce migracyjnej dokonały zasadniczego zwrotu z postawy stosunkowo otwartej ku rozwiązaniom restrykcyjnym. Mimo iż kryzys w kontekście migracyjnym jest definiowany bipolarnie, charakterystyczną cechą zmiany paradygmatu jest koncentracja na eliminacji lub przynajmniej ograniczeniu obecności cudzoziemców na terytorium państwa poprzez kontrole graniczne, utrudnianie dostępu do ochrony międzynarodowej i w kwestii łączenia rodzin, a także zwiększanie skuteczności przymusowych powrotów. Rezultatem podjętych rozważań jest wniosek, że z jednej strony retoryka kryzysu używana przez władze nie oznacza automatycznie wprowadzania regulacji prawnych właściwych stanom 
nadzwyczajnym. Z drugiej zaś narracja nawiązująca do klęski i katastrofy uzasadniała wprowadzanie kontrowersyjnych rozwiązań w dużym pośpiechu, często z lekceważeniem zwykłych w takich wypadkach szczegółowych analiz, oceny skutków regulacji. Jednocześnie istotną determinantą kształtu prawa migracyjnego jest wpisana w paradygmat kryzysu "tymczasowość". Jako jeden z jej najważniejszych elementów traktować należy odejście od gwarantujących pewną stabilność długoterminowych zezwoleń na pobyt w związku z ochroną międzynarodową na rzecz zezwoleń krótkotrwałych.

Słowa kluczowe: nieregularna migracja, kryzys migracyjny, legislacja

Резюме: Цель данной статьи - подробно рассмотреть, как кризисная парадигма влияет на законодательство и практику европейских стран в области нерегулярной миграции. Принимая во внимание, что понятие кризиса неоднозначно и не имеет юридического определения, в первой части статьи разъясняется сфера его применения и контекст, в котором оно используется. Во-вторых, обозначение определенных ситуаций как кризисов требует срочных и чрезвычайных действий. Следовательно, важно указать, какие виды правовых мер и нормативных решений преобладают сегодня в практике отдельных государств. Особый интерес в этом контексте представляют такие страны, как Германия, Швеция или Дания, которые за последние несколько лет осуществили фундаментальный сдвиг в своей миграционной политике от относительно открытого отношения к ограничительным решениям. Хотя кризис в контексте миграции определяется биполярно, характерной чертой смены парадигмы является акцент на устранении или, по крайней мере, ограничении присутствия иностранцев на национальной территории посредством пограничного контроля, препятствуя доступу к международной защите и воссоединению семей, а также повышая эффективность принудительных возвращений. Результатом настоящих рассуждений является вывод о том, что, с одной стороны, риторика кризиса, используемая властями, не означает автоматического введения правовых норм, соответствующих чрезвычайному положению. Однако, с другой стороны, повествование о катастрофе оправдывало поспешное внедрение спорных решений, часто игнорируя обычный в таких случаях детальный анализ и оценку последствий регулирования. В то же время, существенной детерминантой формы миграционного законодательства является «временность», вписанная в парадигму кризиса. Одним из важнейших элементов этой парадигмы является переход от долгосрочных видов на жительство, которые гарантируют определенную стабильность за счет международной защиты к краткосрочным.

Ключевые слова: нерегулярная миграция, миграционный кризис, законодательство

\section{Introduction}

This paper studies the dynamics of migration law in the area pertaining to foreigners in irregular situation. The mention of the "paradigm of the crisis" in the title was motivated by the necessity to distinguish between the presentation of specific phenomena and its perception in public discourse on the one hand, and their objective assessment on the other. ${ }^{1}$ Undoubtedly, the "crisis" narrative surrounding irregular migration is common in the media, political documents, and academic publica-

1 The English Cambridge Dictionary defines the paradigm as a model of something, or a very clear and typical example of something. 
tions, ${ }^{2}$ and has been in use with varying intensity for at least a decade. ${ }^{3}$ Whether or not these diagnoses are accurate, ${ }^{4}$ it should also be noted that the crisis rhetoric can be a useful tool for justifying legislative activities that are often controversial. ${ }^{5}$

Given the above, this study aims to reconstruct the mechanisms of introducing the legal regulations that have been determined by the perception of irregular migration in terms akin to a state of emergency. Undoubtedly, when writing about the crisis narrative in the European context, it should be considered that asylum and migration remain in the area of shared competences between European Union and member States. ${ }^{6}$ However, it seems that the legal provisions created at the EU level have been very widely commented on, ${ }^{7}$ and the comparison of the impact of crisis rhetoric on regulations adopted in individual Member States has some cognitive value. The countries that are particularly interesting in this context include Germany, Sweden, and Denmark, ${ }^{8}$ whose migration policies have, over the course

2 See a large study of the practice crisis labelling in Europe after Arab Spring of 2011: J. Jeandesboz, P. Pallister-Wilkins, Crisis, Enforcement and Control at the EU Borders, in: Crisis and Migration. Critical Perspectives, ed. A. Lindley, London 2014, pp. 115-135.

3 Cf. E. Fontanari, M. Ambrosini, Into the Interstices: Everyday Practices of Refugees and Their Supporters in Europe's Migration 'Crisis', Sociology 2018, vol. 52, no. 3, p. 2; In the worldwide perspective an idea of migration crisis was considered at least in 90' - see e.g. M. Weiner, The Global Migration Crisis. Challenge to States and to Human Rights, New York 1995.

4 It is noteworthy to note works of these researchers, who posit that this term is overused or is used not adequately, cf. C. Menjívar, M. Ruiz, I. Ness, Migration Crisis: Definitions, Critiques and Global Contexts, in: Oxford Handbook of Migration Crisis, eds. C. Menjívar, M. Ruiz, I. Ness, Oxford 2019, p. 2; K.F. Hinterberger, Regularisierungen irregulär aufhältiger Migrantinnen und Migranten. Deutschland, Österreich und Spanien im Rechtsvergleich, Schriften zum Migrationsrecht 2020, vol. 29, p. 37, footnote 2.

5 Cf. S.M. Utych, How Dehumanization Influences Attitudes toward Immigrants, Political Research Quarterly 2018, vol. 71, no. 2, p. 441; S. Carrera, J. Varra, T. Strik, Introduction: Crisis, Rule of Law and Legitimacy, in: Constitutionalising the External Dimensions of EU Migration Policies in Times of Crisis, Legality, Rule of Law and Fundamental Rights Reconsidered, eds. S. Carrera, J.S. Vara, T. Strik, Northampton 2019, p. 2; see case study of the legitimateonature of discourse around immigration: M. Krzyżanowski, "We Are a Small Country That Has Done Enormously Lot": The 'Refugee Crisis' and the Hybrid Discourse of Politicizing Immigration in Sweden, Journal of Immigrant \& Refugee Studies 2018, vol. 16, no. 1-2, pp. 97-112; cf. H. Dijstelbloem, D. Broeders, Border Surveillance, Mobility Management and the Shaping of Non-Publics in Europe, European Journal of Social Theory 2015, vol. 18, no. 1, pp. 21-38.

6 See: Article $77-80$ of the Treaty on the Functioning of the European Union (TFEU), consolidated version OJ C 326, 26.10.2012.

7 Considerations from the EU and international perspective in this field see inter alia T. Gammeltoft-Hansen, N. Tan, The End of the Deterrence Paradigm? Future Directions for Global Refugee Policy, Journal on Migration and Human Security 2017, vol. 5, no. 1, pp. 28-56; R. Byrne, G. Noll, J. Vedsted-Hansen, Understanding of Crisis of Refugee Law: Legal Scholarship and the EU Asylum System, Leiden Journal of International Law 2020, vol. 33, no. 4, pp. 871-892.

8 It has to be mentioned, that Denmark has opted out of the common European asylum and immigration policies - see: Article 1 and 2 of Protocol no. 22 on the position of Denmark, annexed to the Treaty on European Union and the Treaty on the Functioning of the European Union. 
of the past few years, decisively shifted from a relatively open approach towards more restrictive solutions. ${ }^{9}$ It seems important that what these countries have in common is the experience of the heavy influx of third country nationals in a relatively short period of time and a radical change in public opinion. It should be noted that Germany seems to be different, bearing in mind the friendly and open policy of this country towards asylum seekers in the years 2013-2015. Nevertheless, the narrative of a "crisis" appeared in the German public debate in the summer months of 2015, and this date can be considered a time mark of a change of paradigm. ${ }^{10}$

\section{The crisis rhetoric: dynamics, bipolarity, ambivalence}

An analysis of the legal provisions themselves requires the presentation of the basic features of the migration crisis discourse. On the one hand, it often involves naming strategies that cause fear, refer to the risk of destruction, raise suspicions, and criminalise migrants. ${ }^{11}$ On the other hand, the rhetoric of shame and guilt, combined with approval for openness, protectiveness, and solidarity, remains equally strong. ${ }^{12}$ What these two narratives no doubt have in common is the "problematisation" of migrants. ${ }^{13}$

The narratives are also characterised by terminological confusion. Sometimes there is talk of the "migration crisis", at other times of the "refugee crisis", and at yet others of the "humanitarian crisis". This last category is primarily intended to define the extremely difficult position of foreigners themselves, and points to what could be described as the bipolarity of the crisis. The second factor that defines the "crisis"

9 Detailed analysis of this shift in Denmark and Sweden see: A. Hagelund, After the Refugee Crisis: Public Discourse and Policy Change in Denmark, Norway and Sweden, Comparative Migration Studies 2020, vol. 8.

10 See more broadly: V. Hänsel, S. Hess, S. Schurade, Refugee Protection Germany Country Report, Working Papers, Global Migration: Consequences and Responses, Paper 2019/28, December 2019, Georg-August Universität Göttingen, pp. 69-75.

11 Cf. J. Bielecka-Prus, Retoryka lęku przed obcym w polskim dyskursie prasowym, Colloquium Wydziału Nauk Humanistycznych i Społecznych. Kwartalnik 2018, no. 1, pp. 21-22.

12 Cf. ibidem, pp. 19, 24.

13 Cf. D. Bigo, From Foreigners to 'Abnormal Aliens', in: International Migration and Security. Opportunities and Challenges, eds. E. Guild, J. van Selm, London 2006, p. 66; M. Schrover, W. Schinkel, The Introduction: The Language of Inclusion and Exclusion in the Context of Immigration and Integration, Ethnic and Racial Studies 2013, vol. 36, no. 7, p. 1126. 
nature of the situation are the weaknesses of the asylum system, ${ }^{14}$ understood as the difficulties in processing an adequate number of applications and a breakdown of the system of protection..$^{15}$

As a result, public opinion is confronted with a description of the influx of migrants that suggests that the number of migrants is, at the very least, far too great, if not conducive to a demographic disaster. Somewhat parallel to this, an argument of "comforting" or "rationalising" has developed. In this context, it has been argued that, in absolute figures, the influx of irregular migrants into the wealthiest countries and regions of the world is not an unusual situation, ${ }^{16}$ and that the continent of Europe is not the world leader in terms of the number of refugees or immigrants that have been admitted. ${ }^{17}$

In this context, it is no doubt interesting that the "Europisation" of the narrative has led to a specific "transference" of the problems in social perception. ${ }^{18}$ It is difficult to establish when and which of the elements of the crisis situation pertain to Europe as a continent, when to the European Union, and finally, when to particular states. ${ }^{19}$ Naturally, this confusion reflects the complexity of the legal regulations at the domestic and international levels, as well as those adopted in the framework of the EU's common asylum and migration policies. This does not change the fact that using specific data at the macro, European level has the disadvantage of ignoring the differences between the scales of the influx of foreigners into particular countries, as well as the proportion of the number of migrants and the area and population of a given country.

The argument based on numbers is not always adequate either as the numbers themselves do not settle anything in absolute terms. Mass influxes of foreigners can

14 Cf. data and the way the problem is defined by the European Parliament, www.europarl.europa.eu/ news/pl/headlines/society/20170629STO78631/kryzys-migracyjny-w-europie [access: 12.02.2021].

15 See inter alia speech of the Swedish foreign minister, Margot Wallström, https://www.thelocal. se/20151030/in-the-long-run-our-system-will-collapse-in-sweden/ [access: 28.03.2021]; cf. R. Stern, When the ends justify the means? Quality of law-making in times of urgency, The Theory and Practice of Legislation 2019, vol. 7, no. 2, pp. 86-87.

16 Cf. J. Ramji-Nogales, Migration Emergencies, Hastings Law Journal 2017, vol. 68, no. 3, p. 618; R. Stern, When the ends..., p. 85.

17 According to UNHCR's statistics developing countries host $86 \%$ of the world's refugees and Venezuelans displaced abroad, but German ranks fifth in the list of countries hosting refugees, https://www. unhcr.org/refugee-statistics/ [access: 28.03.2021].

18 Cf. J. Bielecka-Prus, Retoryka lęku..., p. 17.

19 Cf. statements made by the minister of the Danish government, Inger Støjberg, In light of the huge influx to Europe these days, there is good reason for us to tighten rules and get that effectively communicated, https://www.thelocal.dk/20150907/denmarks-anti-refugee-ads-published-in-foreign-papers/ [access: 28.03.2021]. 
be socially accepted and approved.$^{20}$ For example, the number of Ukrainians living and working in Poland in recent years, ${ }^{21}$ which consistently fluctuates around one million, has not caused even a fraction of the social controversies or fears ${ }^{22}$ that broke out in response to the prospect of admitting a few thousand refugees in the framework of the so-called quota system..$^{23}$ This can be explained by the cultural, linguistic, and geographic proximity of the Polish and Ukrainian nations, as well as by the fact that this influx has been gradual, controlled, legal, and compliant with the interests of Polish employers. ${ }^{24}$ On the contrary, the unpredictable, sudden influx into the European continent of the peoples who are ethnically, culturally, or religiously foreign is perceived as a crisis and a pressure. ${ }^{25}$

\section{The general characteristic of the changes in domestic legislation caused by the "crisis" rhetoric}

The above-mentioned inconsistencies in the narrative or the assessment of the phenomena in question do not undermine the existence of real problems. Indeed, some European states have struggled with such an influx of foreigners that they have experienced the sense of a loss of control, a lack of adequate preparation, and an urgent need to regain control of the situation. ${ }^{26}$ However, despite many references to states of emergency, none of the European states has decided to employ the mechanisms of derogation linked to the states of emergency in the human rights treaties that is in Article 4 of the International Covenant on Civil and Political Rights (ICCPR) or Article 15 of the European Convention on Human Rights (ECHR). The rhetoric of a disaster and threat used in the migration context has thus far not led to the adoption of the regulations that explicitly introduce the state of emergency.

\footnotetext{
20 Cf. J.Ramji-Nogales, Migration..., p. 613.

21 Cf. M. Troszyński, Ukraina i Ukraińcy w polskich mediach społecznościowych, in: Mniejszość ukraińska i imigranci z Ukrainy w Polsce. Analiza dyskursu. Raport 2, ed. P. Tyma, Warszawa 2019, p. 49.

22 What doesn't change the fact, that the attitude of Polish society towards Ukrainians is complex - see: P. Tyma, Wprowadzenie, in: Mniejszość ukraińska..., pp. 7-37.

23 See: J. Bielecka-Prus, Retoryka lęku..., pp. 8-10.

24 Cf. A. Borowska-Żywno, Pracownicy z Ukrainy na polskim rynku pracy. Szanse, wyzwania i zagrożenia, in: Wspótczesne problemy ekonomiczne w badaniach młodych naukowców, vol. 1. Wzrost, rozwój i polityka gospodarcza, eds. E. Gruszewska, K. Karpińska, A. Protasiewicz, Białystok 2018, p. 123.

25 Cf. M. Dahl, A. Dziudzik, Państwa Unii Europejskiej wobec kryzysu imigracyjnego z 2015 roku, Unia Europejska.pl 2017, vol. 3, p. 17.

26 Cf. R. Stern, When the ends..., p. 87.
} 
Moreover, the term "crisis" itself is never used in legal acts; this rule is proven by the exception of the Hungarian legislation. ${ }^{27}$

In the case of the states that began to tighten their migration policy in 2015, a characteristic pattern of legal regulations can be observed. First, the regulations aim to reduce the influx of third country nationals through the partial reinstating or tightening of border controls and identity verification. In January 2016, the Swedish government introduced new border controls as well as checks on public transport passengers with Denmark, strengthened the police force, and revealed plans to deport up to 80000 foreigners who do not qualify for refugee status. In Denmark, temporary controls at the border with Germany have been introduced, and penalties have been imposed on transport companies for not verifying whether a person has the right to enter Denmark. ${ }^{28}$ Germany reintroduced temporary border controls with Austria in September 2015, which have been continuously extended until now. ${ }^{29}$ Among other instruments limiting the inflow of the third-country nationals, it is necessary to mention re-admission agreements, ${ }^{30}$ the introduction of more restrictive provisions pertaining to family reunification, and more restrictive rules of processing the applications for international protection. ${ }^{31}$

27 Government Decree 269/2015 of 15 September 2015 announcing a crisis situation caused by mass immigration and establishing the rules related to the declaration, maintenance and termination of the crisis situation, unofficial English translation at www.refworld.org/docid/55f90f614.html and in the Hungarian original at http://tinyurl.com/npjg4bn [access: 29.03.2021].

28 Cf. Forslag til lov om ændring af udlændingeloven, Folketinget, LOV no. 1499 af 11/12/2015, 2015/1 LSV 87, https://www.retsinformation.dk/eli/lta/2015/1499 [access: 29.03.2021].

29 See info published at https://www.schengenvisainfo.com/news/germany-extends-border-controls-with-austria-until-november-11/ [access: 29.03.2021].

30 See Administrative Arrangement between the Ministry of Interior of the Kingdom of Spain and the Federal Ministry of Interior, Building and Community of the Federal Republic of Germany on cooperation between Germany and Spain when refusing entry to persons seeking protection in the context of temporary checks at the Internal German-Austrian border, 6.08.2018, available at https:// www.documentcloud.org/documents/5427858- Abkommen-Mit-Spanien.html [access: 20.10.2020]; from 6 August 2018 text in English available at https://s3.documentcloud.org/documents/5427858/ Abkommen-Mit-Spanien.pdf; Administrative Arrangement between the Ministry of Migration Policy of the Hellenic Republic and the Federal Ministry of Interior, Building and Community of the Federal Republic of Germany on cooperation between Germany and Spain when refusing entry to persons seeking protection in the context of temporary checks at the internal German-Austrian border, 18.08.2018, available at https://www.documentcloud.org/documents/5427859-Abkommen-Mit-Griechenland.html [access: 3.10.2021] ; Sweden and Afghanistan signed a memorandum of understanding on the readmission of people whose residence permit applications have been rejected on 5 October 2016. On 4 May 2021, the Administrative Court of Munich found the above mentioned administrative arrangement between Germany and Greece, clearly unlawful and in violation of European Law - see text in German: https://www.proasyl.de/wp-content/uploads/VG-Muenchen04052021-Kammerbeschluss-M-22-E-21.30294.pdf [access: 3.10.2021].

These issues will be discussed further. 
Second, regarding the third-country nationals that have already entered their territories, the states have adopted primarily such measures that allow them to exercise stricter control over the migrants. These include the extension of the grounds for detention, restricting the freedom of movement of the individuals who have already been granted international protection, various forms of invigilation by means of dedicated databases, and the monitoring of foreigners' activities. ${ }^{32}$ These means were strictly connected with steady efforts aiming to improve the percentage of forced returns. ${ }^{33}$

The crisis caused by Coronavirus infections have not changed this situation. Due to the pandemic, detained third-country nationals in Germany have been transferred to centres for asylum seekers on condition that they do not leave those sites. Yet, the plans to perform as many forcible returns as possible have not been abandoned. This raises serious doubts because the destinations of deportation will likely include countries with very poor healthcare, thereby exposing foreigners to the risk of a COVID-19 infection. ${ }^{34}$

Sweden, in turn, released some of the detainees to reduce the density in detention centres. Other than that, however, non-governmental organisations report that many of the recommendations of sanitary authorities have not been applied, and the access to medical staff, coupled with the high percentage of infections, remains a problem. ${ }^{35}$

\section{Haste, lack of rationality, negligent legislation}

One of the important consequences of perceiving a given situation in terms of the state of emergency is the belief that existing legal measures and solutions are inadequate and have to some extent failed. If we add to that the rhetoric of "breakdown"

32 Cf. E. Hofverberg, Denmark, in: Refugee Law and Policy in Selected Countries, 2016 [online], electronic publication published at https://www.loc.gov/law/help/refugee-law/denmark.php\#_ftn63 [access: 31.03.2021], see in Germany Gesetz zur Verbesserung der Registrierung und des Datenaustausches zu aufenthalts- und asylrechtlichen Zwecken, 2.02.2016, BGBL 2016, Teil I, no. 5.

33 This was the reason for the introduction of the 'Second Law on the Better Implementation of the Obligation to Exit the Federal Republic of Germany' - see in German language Zweites Gesetzes zur besseren Durchsetzung der Ausreisepflicht, 20.08.2019, BGBKL 2019, Teil I, no. 31, p. 1294.

34 According to the German media, there have been flights to Africa and Pakistan and since December 2020, deportations to Afghanistan have taken place, https://www.infomigrants.net/en/post/29922/ coronavirus-germany-loses-sight-of-its-refugees [access: 30.03.2021].

35 See information published by Global Detention Project, https://www.globaldetentionproject.org/ countries/europe/sweden [access: 30.03 .2021 ]. 
and an atmosphere verging on panic, swift legislative changes facilitating a proper response seem urgent and necessary. Undoubtedly, the perception of an influx of third-country nationals as an emergency has led to the securitisation of refugee-migration and created the need to regain control. ${ }^{36}$ Putting aside the necessity of the legislative amendments themselves, their frequency and speed needs to be criticised. It is estimated that Denmark has passed almost 70 amendments between 2015 and 2018, ${ }^{37}$ but that wasn't the end of the legislation. In the following years, the process of reshaping the Danish immigration and asylum model continued, especially in 2019, when a so-called "paradigm shift" was observed. ${ }^{38}$ As noted in the scientific literature, the fast legislative procedure at that time made it difficult to deeply and more accurately assess the impact of these solutions on integration and practice. ${ }^{39}$

In Germany, many significant legislative changes began on 24 October 2015, when the 'Act on the Acceleration of Asylum Procedures' (called Asylum Package I) entered in force. ${ }^{40}$ The so-called "migration package", introduced between 2019 and 2020, deserves special attention, which extensively amended practically all elements of the status of third country nationals including asylum seekers. ${ }^{41}$

Swedish law has been substantially amended in 2016 by Temporary Law, while the excessive haste and lack of a proper preparation of these amendments was strongly criticised. Scholars rightly argue that both the adoption of solutions that do not comply with the principle of proportionality, because of the lack of proper preparation and analysis of the problem, have been coupled with an uninformed

36 See: V. Hänsel, S. Hess, S. Schurade, Refugee Protection..., p. 82.

37 Cf. Global Detention Project, Country Report Immigration Detention in Denmark: Where Officials Cheer the Deprivation of Liberty of "Rejected Asylum Seekers", May 2018, p. 5.

38 Cf. Section 7 (1) and (2) and Section 8 (1) and (2) of the Danish Aliens Act, as amended by Act No. 174 of 27 February 2019 - text in English Aliens (Consolidation) Act No. 239 of 10 March 2019 published at https://www.nyidanmark.dk/en-GB/Lovstof/legislation; official consolidated version in Denmark: Bekendtgørelse af udlændingeloven LBK no. 239, 10.03.2019.

39 J.-P. Brekke, J. Vedsted-Hansen, R. Thorburn Stern, Temporary Asylum and Cessation of Refugee Status in Scandinavia. Policies, Practices and Dilemmas, European Migration Network, 2020, p. 15.

40 Asylverfahrensbeschleunigungsgesetz vom 20. Oktober 2015, BGBL 2015, Teil I, no. 40. Through this amendment the 'Asylum Procedure Act' (Asylverfahrensgesetz - AsylVfG) changed name to the 'Asylum Act' (Asylum Act - AsylG) - see in German language: "Asylgesetz in der Fassung der Bekanntmachung vom 2. September 2008 (BGBl. I S. 1798), das zuletzt durch Artikel 9 des Gesetzes vom 9. Juli 2021 (BGBl. I S. 2467) geändert worden ist”.

41 See more: Informationsverbund Asyl und Migration, Neuregelungen durch das Migrationspaket. Überblick über aktuelle Gesetzesänderungen im Asyl-, Aufenthalts- und Sozialrecht, in: Das Migrationspaket, Beiträge zu den aktuellen gesetzlichen Neuerungen im Asyl- und Aufenthaltsrecht sowie in weiteren Rechtsgebieten, Beilage zum Asylmagazin 8-9/2019, pp. 2-14. 
public debate. ${ }^{42}$ According to the Government Bill, the effectiveness of Temporary Law from 2016 should be subject to a mid-term review, but this was never carried out. $^{43}$

Characteristic of these tendencies are the adoption of legal solutions that contradict expert knowledge and the perception of particular mechanisms only from a national perspective when, in fact, they are of international nature. ${ }^{44}$ One of the most important mechanisms behind the introduction of specific regulations is the conviction of the authorities of particular states that when they tighten their migration policy they "send a message" to third-country nationals, effectively influencing these people's decisions about the time and place of their emigration. ${ }^{45}$ Yet, academic analyses show that the factors determining whether a person enters this or that country are multifaceted and far more complex. ${ }^{46}$

As has been mentioned above, crisis events are, as a rule, linked to the exhaustion of prior solutions. Yet, despite all the talk of the "unprecedented" influx of foreigners, it is difficult to find any new approach or concepts in the provisions of migration law. Granted, there is an element of distrust towards the institutions perceived as obsolete; for example, there are doubts as to the relevance and adequacy of refugee law measures. However, this is not followed by any substantial change in the sense that the regulations introduced maintain the basic distinction between refugees, who deserve protection, and "economic migrants", who do not. ${ }^{47}$

The return policy is characterised by similar tendencies. No new solutions have been developed in this area; instead, provisions have been introduced whose primary aim is to increase the percentage of - let us add, predominantly forcible - returns. Yet, scholars argue that the return policy should be measured not only by the

42 Cf. R. Stern, When the ends..., p. 86; Informationsverbund Asyl..., p. 2.

43 Cf. Government Bill prop. 2018/19:128, Section 5.4 and the Migration Court of Appeal in MIG 2018:20 quoting from: J.-P. Brekke, J. Vedsted-Hansen, R. Thorburn Stern, Temporary Asylum..., p. 25.

44 Cf. M. Zambroni, Swedish Legislation and the Migration Crisis, The Theory and Practice of Legislation 2019, vol. 7, no. 2, pp. 118-119.

45 See campaign of the Danish government in the Libyan media of 2015, https://www.thelocal. dk/20150907/denmarks-anti-refugee-ads-published-in-foreign-papers/ [access: 26.02.2021].

46 See: EASO, Significant Pull/Push Factors for Determining of Asylum-Related Migration. A Literature Review, EASO 2016, pp. 29-30; H. de Haas, M. Czaika, M.-L. Flahaux, E. Mahendra, K. Natter, S. Vezzoli, V. Villares-Varela, International Migration: Trends, Determinants, and Policy Effects, Population and Development Review 2019, vol. 45, no. 4, p. 907.

47 See studies devoted to possible approach changes: T. Gammeltof-Hanssen, N. Tan, The End of the Deterrence Paradigm..., pp. 45-47; J. Ramji-Nogales, Moving Beyond Refugee Law Paradigm, AJIL Unbound 2017, vol. 111, pp. 8-12. 
number of deportations but also by their sustainability, which is greater in the case of voluntary return. ${ }^{48}$

\section{Long-term (permanent) temporariness and protracted exclusion}

The use of the term "crisis" implies a deviation from the norm, a temporary breakdown that must be overcome so that the desired, proper situation can be reestablished. It seems that a long perspective of the migration crisis's existence should pose the question whether we are indeed still dealing with a deviation from the norm. The observed direction of the amendments to migration law does not display the acknowledgment of the fact that migration influxes are a permanent process. ${ }^{49}$ The long-term nature of the current situation is responded to by making permanent the "temporariness" that is inscribed in the status of irregular migrants and refugees. This directly translates into the introduction of such legal solutions that do grant legal residence, but only for a limited period, connected with renewed focus on temporary protection, temporary permits, revocation, ${ }^{50}$ and the cessation of international protection. ${ }^{51}$ In Denmark, the normal duration of the validity of the initial temporary residence permits for refugees and persons with subsidiary protection was reduced from five years to two years and one year, respectively. ${ }^{52}$ At the same time, the extension of the residence permit on the expiration of each period of validity has to be decided in the same manner as the initial application for asylum. ${ }^{53}$

48 Cf. R. Ruben, M. van Houte, T. Davids, What Determines the Embeddedness of Forced-Return Migrants? Rethinking the Role of Pre- and Post-Return Assistance, International Migration Review 2009, vol. 43, no. 4, pp. 908-937; K. Kushminder, Interrogating the Relationship between Remigration and Sustainable Return, International Migration 2017, vol. 55, no. 6, pp. 107-121.

49 Cf. E. Fontanari, M. Ambrosini, Into the Interstices..., p. 3.

50 See: Articles 11 and 16 of the Directive 2011/95/EU of the European Parliament and of the Council of 13 December 2011, on standards for the qualification of third-country nationals or stateless persons as beneficiaries of international protection, for a uniform status for refugees or for persons eligible for subsidiary protection, and for the content of the protection granted, OJ 2011 L 337/9, 20.12.2011. In Sweden see Chapter 4, Sections 5 and 5 a of the Aliens Act.

51 Cessation of the international protection is regulated in Article $1 \mathrm{C}$ (5) The Convention Relating to the Status of Refugees, Geneva 28 July 1951, United Nations, Treaty Series, vol. 189, p. 137; J.-P. Brekke, J. Vedsted-Hansen, R. Thorburn Stern, Temporary Asylum..., 2020.

52 Cf. Ministerial Order No. 109 of February 3, 2016, amending Section 16 of Ministerial Order No. 375 of 20 March 2015.

53 See time limitations for residence permit in Article 7 (1, 2, 3) Danish Aliens Act; T. Gammeltoft-Hanssen, N. Tan, The End of the Deterrence Paradigm..., pp. 38-39. See detailed analysis: J.P. Brekke, J. Vedsted-Hansen, R. Thorburn Stern, Temporary Asylum..., pp. 15-17. 
These normative solutions mirrored the so-called "paradigm shift" from long-term integration to short-term stay, with a focus on returning individuals as soon as possible. In UNHCR assessment, this law places a disproportionate emphasis on the temporariness of asylum. ${ }^{54}$ In Germany, strict preconditions for the residence of people with tolerated stay (Duldung) were introduced. ${ }^{55}$

Thus understood, temporariness is not only connected with the conditionality of the right of residence, but also to a form of permanent exclusion from a given society. One good example of this phenomenon is control through "campization. ${ }^{36}$ Germany has obliged asylum seekers to stay in initial reception centres for up to 18 months. ${ }^{57}$ Although such centres are not closed, their isolated and remote locations make it difficult for their residents to access healthcare and social welfare services, and the actual limitations of their freedoms are significant. ${ }^{58}$

It is important to note that some of the "crisis regulations" are socially accepted because, at least in principle, they are supposed to be temporary ${ }^{59}$ Naturally, introducing temporarily valid solutions is a reasonable measure, but, with time, adopted regulations turn out to be far more permanent than originally declared. Although the German provisions of 2016 that oblige the individuals granted international protection to live on the territory of a particular land or city were to remain in force for three years, they are now binding for an indefinite period ${ }^{60} \mathrm{~A}$ similar sit-

54 UNHCR, UNHCR Recommendations to Denmark on Strengthening Refugee Protection in Denmark, Europe and Globally, January 2021, p. 2, https://www.unhcr.org/neu/49885-recommendations-to-denmark-on-strengthening-refugee-protection.html [access: 2.12.2021].

55 See $\$ 60$ a Aufenthaltgesetz. Tolerated stay means in this case, that person is abliged to leave the country, but cannot currently be deported. This doesn't constitute resident permit but no cause criminal liability for illegal stay according to $₫, 95 \S 1$ No. 2 AufenthG.

56 Cf. V. Hänsel, S. Hess, S. Schurade, Refugee Protection ..., pp. 75-76; R. Kreichauf, From Forced Migration to Forced Arrival: The Campization of Refugee Accommodation in European Cities, Comparative Migration Studies 2018, vol. 6 (7), p. 7.

57 Cf. $\$ 47$ (1) Asylgesetz; additionaly freedom of movement people in asylum procedures is generally limited to the district of the foreigners' authority in which the responsible reception centre is located cf. $\$ 55$ (1) and 56 (1) Asylgesetz. This is fundamental change in comparison with previous provisions where 6 months was foreseen - see: J. Wiebke, Druck auf die Länder? Lex AnkER im »II. Hau-Ab-Gesetz«, in: Das Migrationspaket..., pp. 73-75.

58 UN Committee against Torture (CAT), Concluding Observations on the Sixth Periodic Report of Germany, CAT/C/DEU/CO/6, 11.07.2019, https://bit.ly/382KcoE [access: 26.02.2021].

59 E.g., the amendment to German law that makes it possible to detain migrants in prisons, rather than not only in dedicated detention centres, was introduced for the period of three years, until June 2022. Cf. R. Kostner, R. Steiner, Widerstand gegen das Geordnete-Rückkehr-Gesetz, https://www.sueddeutsche.de/ politik/geordnete-rueckkehr-gesetz-bundesrat-vermittlungsausschuss-1.4484319 [access: 26.02.2021].

60 Cf. $\$ 12$ a Aufenfthaltgesetz. It is noteworthy to mention, that this is different type of limitation than "geographical restriction" or "residence obligation" (Residenzpflicht) under Asylgesetz mentioned above. It was introduced by Integration Act of 31 July 2016, 5.08.2016, BGBL, Teil I, no. 39, p. 1939. 
uation happened in Sweden, where the act introducing "temporary" restrictions on residence permits was adopted in 2016. ${ }^{61}$ Temporary law was replaced on 20 July 2021 by new rules in the Aliens Act, but was assessed as more far-reaching than the temporary law was, and affect almost all those who apply for a residence permit in Sweden. ${ }^{62}$

In all analysed states cuts or lowering of social benefits was observed and right to family reunification was limited. ${ }^{63}$ Between 2016 and 2019, beneficiaries of temporary protection in Sweden were not entitled to family reunification. ${ }^{64}$ In February 2016, the suspension of the right to family reunification for persons with temporary protection status in Denmark was extended from one year to a period of three years. ${ }^{65}$ It is noteworthy that this suspension, combined with the refusal to allow exemption from the three years' waiting period under narrowly defined criteria, was recognized very recently by the European Court of Human Rights as a violation of the right to family life under Article 8 of the European Convention on Human Rights. ${ }^{66}$ In Germany on 17 March 2016, the 'Asylum Package II' entered into force, in which the right to family reunification for refugees entitled to subsidiary protection status was to be suspended until March $2018 .{ }^{67}$ In 2018, subsidiary protection holders were again entitled to family reunification, but - according to the new law provisions - this is limited to a monthly contingent of 1,000 cases. ${ }^{68}$ This regulation

61 On 18 June 2019, the Swedish Parliament (Riskdag) extended the Temporary Law on residence permits until July 2021. Temporary Law was introduced by Lag om tillfälliga begränsningar av möjligheten att få uppehållstillstånd i Sverige 2016:752: consolidated version of this law in Swedish accessible https:// www.riksdagen.se/sv/dokument-lagar/dokument/svensk-forfattningssamling/lag-2016752-om-tillfalliga-begransningar-av_sfs-2016-752 [access: 30.11.2021].

62 Utlänningslag (2005:716) text published in electronic version: https://www.riksdagen.se/sv/dokument-lagar/dokument/svensk-forfattningssamling/utlanningslag-2005716_sfs-2005-716 [access: 26.02.2021]. See official site of the Swedish Migration Agency: https://www.migrationsverket.se/English/About-the-Migration-Agency/Changes-to-the-Swedish-Aliens-Act-in-2021.html [access: 26.02.2021].

63 Proposal for an Act amending the Act on Active Social Policy, the Act on Active Employment Efforts, the Integration Act and various other acts L 2, 2014-2015, Forslag til lov om ændring af lov om aktiv social politik, lov om en aktiv beskæftigelsesindsats, integrationsloven og forskellige andre love.

64 Law on temporary limitations to the possibility of being granted a residence permit in Sweden, 2016:752. This the ban was removed 20 July 2019, 2019, p. 481.

65 Section 9 (1), (i) (d), (ii) (d), and (iii) (d) of the Aliens Act, as amended by Act No. 102 of 3 February 2016.

66 Judgment of The Grand Chamber of the European Court of Human Rights, M.A. v. Denmark, application no. 6697/18, 9.07.2021, $\$ 193-194$. The Convention for the Protection of Human Rights and Fundamental Freedoms, opened for signature in Rome on 4 November 1950, ETS 5, as amended by the provisions of Protocol No. 15, CETS No. 213.

67 Cf. \$104 (13) Aufenthgesetz, L 2, 2014-2015.

68 Cf. $\$ 36$ a (12) Aufenthaltgesetz. 
poses the question as to whether family reunification is still a right or an act of benevolence of government. ${ }^{69}$

It is also worth mentioning that the body of the states' regulations pertaining to migration and asylum is characterised by a disproportion between the provisions that control and punish migrants and those that protect their rights. The deficiencies in question include the lack of implementation or proper application of the standards that prohibit the punishing of human trafficking victims for the violations of migration law committed in connection to being trafficked..$^{70}$ People in an irregular situation not only live in the territories of these states, but also require some activities on their part, for example, the determination of the conditions of accessing COVID-19 vaccinations. ${ }^{71}$

\section{Between wide discretion and the arbitrariness of administrative power}

Migration law lies within the jurisdiction of the executive power in that it regulates the tasks and competences of public administration in the area of controlling the state's territory. However, in crisis situations, which require swift responses, decision processes are even more extensively shifted to administrative authorities. This also means that the provisions of migration law pertaining to the control over third country nationals are highly restrictive and formulated in such terms that allow for their application in a wide range of circumstances. Two types of regulations can be observed here: the first type includes provisions that are very detailed and that enumerate extensive catalogues of premises. The latest amendments to German law formulate six criteria justifying the rebuttable presumption of the risk of absconding ( $\$ 62$, Article 3a of Aufenthaltgesetz) and a separate catalogue of seven circumstances proving this risk ( $\$ 62$, Article $3 \mathrm{~b}$ of the same act). The relationship between

69 Cf. V. Hänsel, S. Hess, S. Schurade, Refugee Protection..., p. 63.

70 Y. Jin Shin, A Transnational Human Rights Approach to Human Trafficking Empowering the Powerless, Leiden, Boston 2017, pp. 19-26; A. Gallagher, Human Rights and the New UN Protocols on Trafficking and Migrant Smuggling: A Preliminary Analysis, Human Rights Quarterly 2001, vol. 23, pp. 990-993; J.C. Hathaway, The Human Rights Quagmire of 'Human Trafficking', Virginia Journal of International Law 2008, vol. 49, no. 1, pp. 2-3; D. Kyle, R. Koslowski, Introduction, in: Global Human Smuggling. Comparative perspective, eds. D. Kyle, R. Koslowski, Baltimore 2011, pp. 20-22.

71 Germany is positive example of giving access irregular migrants and asylum seekers vaccinations, but there is no information about inclusion of undocumented migrants and asylum seekers in Denmark and Sweden - see Platform for International Cooperation on Undocumented Migrants, https://picum. org/undocumented-people-and-the-covid-19-vaccines-what-is-europe-doing/ [access: 31.03.2021]. 
$\$ 62$, Article $3 \mathrm{a}$ and $₫ 62$, Article $3 \mathrm{~b}$ of Aufenthaltgesetz is not clear, because detention can be ordered in all of the thirteen cases enumerated in both provisions, ${ }^{72}$ and in two others defined by the Dublin procedure ( $\$ 2$, Article 14 of Aufenthaltgesetz).

The second type includes relatively concise provisions which, however, are formulated in a flexible way and frequently employ general clauses, allowing for their being used in a wide range of circumstances. The fact that the provisions of migration law are characterised by a certain degree of flexibility and open-endedness is a neutral phenomenon, provided that this is an adequate form of regulation. It is even advisable in the cases where closed enumerations or excessively detailed regulations would result in loopholes or deprive administrative authorities of necessary leeway in making a decision. However, in this case the provisions are overly general, which violates the standard of the predictability of law, sometimes even coming close to granting administrative authorities with law-making competences in the process of law application. ${ }^{73}$ Sometimes, the issue in question can be observed in the case of particular provisions, such as the open-ended formula of "avoiding or obstructing return."

The discretion of administrative authorities provided for by the legislature requires proper mechanisms of judicial control. One of the most interesting examples is the Danish Aliens Act that entered into force on 20 November 2015, as set out in the legislative proposal no. L 62, which allows the temporary suspension of fundamental legal safeguards in situations of a high influx of migrants qualified as "special circumstance." 75 According to these provisions, the court hearings no longer have to take place within 72 hours of arrest, but "as soon as possible" and only at the request of the applicant. This was justified by the inability to enforce safeguards that normally govern the use of detention during periods of a high influx of asylum-seekers. ${ }^{76}$ In essence, however, UNHCR doubted whether such solutions did not actually facilitate administrative expediency, which is not a legitimate purpose of migration detention. ${ }^{77}$ The lack of appropriate procedural guarantees

72 Cf. S. Keßler, Freiheitsentzug ad libitum? Die Auswirkungen des „Hau-Ab-Gesetzes II” auf die Abschiebungshaft, in: Das Migrationspaket..., pp. 44-45.

73 See: M. Zambroni, Swedish Legislation..., p. 108.

74 See: I. Majcher, The Return Directive 2008/115/EC. European Implementation Assessment, ed. K. Eisele, Brussels 2020, p. 89.

75 UNHCR, UNHCR Observations on amendments to the Danish Aliens Act as set out in Lovforslag nr. L 62, January 2016, https://www.ecoi.net/en/file/local/1279094/1930_1452673777_5694ecf64.pdf [access: 2.10.2021].

76 Ibidem, $\$ 9$.

77 See: ibidem, $\$ 12$; Human Rights Committee recommended repeal of this amendment in Concluding Observations in 2016, CCPR/C/DNK/CO/6, 25.08.2016, $\$ 32 \mathrm{~d}$. 
was accompanied by another amendment to the Act on foreigners, adopted in 2016, which introduced the possibility of confiscating the property of asylum seekers in order to compensate for the costs of their admission. ${ }^{78}$

Another problem that we seem to observe in many European countries is the retreat of judges into the position of the notaries of the decisions issued by administrative authorities. Courts often treat the latter as experts in migration cases, rather than the organs whose decisions need to be controlled. It seems that this tendency is characteristic of civil or criminal courts, whose jurisdiction in migration cases is not linked to expertise in this area. ${ }^{79}$

\section{Conclusion}

To summarise the above considerations, it should be observed that, in response to the heavy influx of foreigners and the narrative that surrounded it, various countries cited the state of emergency or the crisis of the state to introduce new legal provisions. These regulations were made in great haste, often neglecting the detailed analyses and impact assessment required in such circumstances, and even bypassing the procedures that accompany the legislative process. Doubtless, their characteristic feature is being directed towards the elimination or at least reduction of the presence of foreigners in the state's territory through border control, impeding the access to international protection and family reunification, as well as increasing the efficiency of forcible returns. It needs to be emphasised that the provisions adopted in the context of the crisis have at least partially been shaped by a national perspective, that is, the assumption that the regulations of the target state are the main factor determining migration influxes.

78 UNHCR, UNHCR Observations on the proposed amendments to the Danish Aliens legislation L 87, 6 January 2016, $\$ 4152$, https://www.refworld.org/docid/5694ed3a4.html. It should be noted, however [access: 2.10 .2021 , that this provision was not applied in practice.

79 This problem has been observed in many European countries as well, see: M. Moraru, G. Renaudiere, European Synthesis Report on the Judicial Implementation of Chapter IV of the Return Directive Pre-Removal Detention, Research Report 2016/5, European University Institute, pp. 28-29. Global Detention Project, Immigration Detention in Belgium: Covid-19 Puts the Brakes on an Expanding Detention System, Global Detention Project 2020, p. 16. Cf. T. Sieniow, Stosowanie alternatyw do detencji cudzoziemców w Polsce w latach 2014-2015. Raport z monitoringu, Lublin 2016, p. 82; F. Crépeau, Report by the Special Rapporteur on the Human Rights of Migrants, François Crépeau, on his Mission to Italy (29 September -8 October), A/HRC/23/46/Add.3, Human Rights Council, 2012, http://www. ohchr.org/EN/IssuES/Migration/SRMigrants/PagES/CountryVisits.aspx [access: 30.03.2021]. 
Some of these measures have been introduced as temporary solutions, but there is a clear tendency to uphold them. Although the migration crisis has been defined bipolarly, the legal provisions that criminalise, control and, counteract irregular migration remain the basic catalogue of the measures applied to irregular foreigners. These are predominantly reactive solutions, coupled with the states' wishful thinking based on the following assumption: treat the foreigners badly enough, and they will return whence they came. The COVID-19 pandemic has not so far changed this trend in any significant way.

Translated by Jarosław Szymański

\section{Bibliography}

Bielecka-Prus J., Retoryka lęku przed obcym w polskim dyskursie prasowym, Colloquium Wydziału Nauk Humanistycznych i Społecznych AMW. Kwartalnik 2018, no. 1.

Bigo D., From Foreigners to 'Abnormal Aliens', in: International Migration and Security. Opportunities and Challenges, eds. E. Guild, J. van Selm, London 2006.

Borowska-Żywno A., Pracownicy z Ukrainy na polskim rynku pracy. Szanse, wyzwania i zagrożenia, in: Wspólczesne problemy ekonomiczne w badaniach młodych naukowców, vol. 1. Wzrost, rozwój i polityka gospodarcza, eds. E. Gruszewska, K. Karpińska, A. Protasiewicz, Białystok 2018.

Brekke J.P., Vedsted-Hansen J., Thorburn Stern R., Temporary Asylum and Cessation of Refugee Status in Scandinavia. Policies, Practices and Dilemmas, European Migration Network, 2020.

Byrne R., Noll G., Vedsted-Hansen J., Understanding of Crisis of Refugee Law: Legal Scholarship and the EU Asylum System, Leiden Journal of International Law 2020, vol. 33, no. 4.

Carrera S., Vara J.S., Strik T., Introduction: Crisis, Rule of Law and Legitimacy, in: Constitutionalising the External Dimensions of EU Migration Policies in Times of Crisis. Legality, Rule of Law and Fundamental Rights Reconsidered, eds. S. Carrera, J.S. Vara, T. Strik, Northampton 2019.

Dahl M., Dziudzik A., Państwa Unii Europejskiej wobec kryzysu imigracyjnego z 2015 roku, Unia Europejska.pl 2017, no. 3.

Dijstelbloem H., Broeders D., Border Surveillance, Mobility Management and the Shaping of Non-Publics in Europe, European Journal of Social Theory 2015, vol. 18, no. 1.

EASO, Significant Pull/Push Factors for Determining of Asylum-Related Migration. A Literature Review, EASO 2016.

Fontanari E., Ambrosini M., Into the Interstices: Everyday Practices of Refugees and Their Supporters in Europe's Migration 'Crisis', Sociology 2018, vol. 52, no. 3.

Gallagher A., Human Rights and the New UN Protocols on Trafficking and Migrant Smuggling: A Preliminary Analysis, Human Rights Quarterly 2001, vol. 23. 
Gammeltoft-Hansen T., Tan N., The End of the Deterrence Paradigm? Future Directions for Global Refugee Policy, Journal on Migration and Human Security 2017, vol. 5, no. 1.

Global Detention Project, Country Report Immigration Detention in Germany: From Open Arms to Public Backlash, Global Detention Project 2020.

Global Detention Project, Immigration Detention in Belgium: Covid-19 Puts the Brakes on an Expanding Detention System, Global Detention Project 2020.

Haas de H., Czaika M., Flahaux M.-L., Mahendra E., Natter K., Vezzoli S., Villares-Varela V., International Migration: Trends, Determinants, and Policy Effects, Population and Development Review 2019, vol. 45, no. 4.

Hagelund A., After the Refugee Crisis: Public Discourse and Policy Change in Denmark, Norway and Sweden, Comparative Migration Studies 2020, vol. 8, DOI: 10.1186/s40878-0190169-8.

Hänsel V., Hess S., Schurade S., Refugee Protection Germany Country Report, Working Papers, Global Migration: Consequences and Responses, Paper 2019/28, December 2019, Georg-August Universität Göttingen.

Hathaway J.C., The Human Rights Quagmire of 'Human Trafficking', Virginia Journal of International Law 2008, vol. 49, no. 1.

Hinterberger K.F., Regularisierungen irregulär aufhältiger Migrantinnen und Migranten. Deutschland, Österreich und Spanien im Rechtsvergleich, Schriften zum Migrationsrecht 2020, vol. 29.

Jeandesboz J., Pallister-Wilkins P., Crisis, Enforcement and Control at the EU Borders, in: Crisis and Migration. Critical Perspectives, ed. A. Lindley, London 2014.

Jin Shin Y., A Transnational Human Rights Approach to Human Trafficking. Empowering the Powerless, Leiden, Boston 2017.

Keßler S., Freiheitsentzug ad libitum? Die Auswirkungen des „Hau-Ab-Gesetzes II” auf die Abschiebungshaft, in: Das Migrationspaket, Beiträge zu den aktuellen gesetzlichen Neuerungen im Asyl- und Aufenthaltsrecht sowie in weiteren Rechtsgebieten, Beilage zum Asylmagazin 2019, no. 8-9.

Kmak M., Seilonen A., Balancing Control with Rights. Immigration Detention in Finland, in: Immigration Detention. The Migration of a Policy and Its Human Impact, eds. A. Nethery, S.S.J. Silverman, Routledge 2014.

Kreichauf R., From Forced Migration to Forced Arrival: The Campization of Refugee Accommodation in European Cities, Comparative Migration Studies 2018, vol. 6 (7).

Krzyżanowski M., "We Are a Small Country That Has Done Enormously Lot": The 'Refugee Crisis' and the Hybrid Discourse of Politicizing Immigration in Sweden, Journal of Immigrant \& Refugee Studies 2018, vol. 16, no. 1-2.

Kushminder K., Interrogating the Relationship between Remigration and Sustainable Return, International Migration 2017, vol. 55, no. 6.

Kyle D., Koslowski R., Introduction, in: Global Human Smuggling. Comparative Perspectives, eds. D. Kyle, R. Koslowski, Baltimore 2011.

Majcher I., The Return Directive 2008/115/EC. European Implementation Assessment, ed. K. Eisele, Brussels 2020.

Menjívar C., Ruiz M., Ness I., Migration Crisis: Definitions, Critiques and Global Contexts, in: Oxford Handbook of Migration Crisis, eds. C. Menjívar, M. Ruiz, I. Ness, Oxford 2019. 
Moraru M., Renaudiere G., European Synthesis Report on the Judicial Implementation of Chapter IV of the Return Directive Pre-Removal Detention, REDIAL Research Report 2016/5, European University Institute.

Ramji-Nogales J., Migration Emergencies, Hastings Law Journal 2017, vol. 68, no. 3.

Ramji-Nogales J., Moving Beyond Refugee Law Paradigm, AJIL Unbound 2017, vol. 111.

Ruben R., van Houte M., Davids T., What Determines the Embeddedness of Forced-Return Migrants? Rethinking the Role of Pre-and Post-Return Assistance, International Migration Review 2019, vol. 43, no. 4.

Schrover M., Schinkel W., The Introduction: The Language of Inclusion and Exclusion in the Context of Immigration and Integration, Ethnic and Racial Studies 2013, vol. 36, no. 7.

Sieniow T., Stosowanie alternatyw do detencji cudzoziemców w Polsce w latach 2014-2015. Raport $z$ monitoringu, Lublin 2016.

Stern R., When the Ends Justify the Means? Quality of Law-Making in Times of Urgency, The Theory and Practice of Legislation 2019, vol. 7, no. 2.

Troszyński M., Ukraina i Ukraincy w polskich mediach społecznościowych, in: Mniejszość ukrainska i migranci z Ukrainy w Polsce. Analiza dyskursu. Raport 2, ed. P. Tyma, Warszawa 2019.

Utych S.M., How Dehumanization Influences Attitudes toward Immigrants, Political Research Quarterly 2018, vol. 71, no. 2.

Weiner M., The Global Migration Crisis. Challenge to States and to Human Rights, New York 1995.

Wiebke J., Druck auf die Länder? Lex AnkER im »II. Hau-Ab-Gesetz«, in: Das Migrationspaket, Beiträge zu den aktuellen gesetzlichen Neuerungen im Asyl- und Aufenthaltsrecht sowie in weiteren Rechtsgebieten, Beilage zum Asylmagazin 2019, no. 8-9.

Zambroni M., Swedish Legislation and the Migration Crisis, The Theory and Practice of Legislation 2019, vol. 7, no. 2. 
